\title{
Chapter 1 \\ Beyond the Western Horizon: Rethinking Education, Values, and Policy Transfer
}

\author{
Iveta Silova, Jeremy Rappleye, and Euan Auld
}

\subsection{Introduction}

Over the past four decades, the dominant understanding of education policy has shifted dramatically. In the past, education policy was seen as a reflection of particular historical, political, social, economic, and cultural configurations of a given country. Today, policy is increasingly understood as heavily influenced by extra-national forces, so much so that policies "elsewhere" are seen as possible reform options. This has given rise to many dominant trends in education policy today: the OECD's Programme for International Student Achievement (PISA), the discourses of "best practice," the dominance of the World Bank in the "developing" world, and now even attempts to borrow from "high performing" countries to improve education policy and practice at home. Examples include the United Kingdom's well-publicized attempts to borrow Shanghai Math, American ongoing efforts to import Japanese Lesson Study, and an increasing interest among policymakers globally to transfer an illusive "Finnish PISA miracle" into different education contexts.

Yet, this perspective is not new. All modern education systems arose relationally, be it through purposeful learning from systems elsewhere or by forceful implant by colonizing powers. Notable examples of the former include American interest in the Prussian system (Horace Mann), Japanese study of the American system (Iwakura Mission), and China's import of the Japanese system (Qing Imperial Court Mission 1896). The latter include British education in India (Macaulay) and Hong Kong, the

I. Silova $(\bowtie)$

Mary Lou Fulton Teachers College, Arizona State University, Tempe, AZ, USA

e-mail: Iveta.Silova@asu.edu

J. Rappleye

Graduate School of Education, Kyoto University, Kyoto, Japan

E. Auld

The Education University of Hong Kong, Hong Kong SAR, China 
United States in the Philippines and Hawaii, and Japan in Korea and Taiwan. Viewed against this larger historical span, the recent shift to an extra-national perspective for policy studies is not a novel development, but a return to the recognition that modern education and education policy are inevitably entangled with the world beyond one's own national borders.

Where difference does arise is in the levels of recognition of global entanglement. Arguably most non-Western countries cannot even imagine education or education policy without reference to the Western world: the legacy of Western colonization remains too powerful, Western-led development ensures constant comparison, or the analytical frameworks that are used to understand education remain imbued with the Western experience. In these contexts - the majority in the worldeducation policy inevitably and automatically invokes comparison and contextualization in the wider world. In contrast, most Western countries still lack recognition of education policy as relational and globally entangled. Having never experienced colonization (i.e., the receiving end) and viewing their analytical frameworks as universal rather than particular, these countries - the minority in the world - are only now coming to recognize the comparative, global dimensions of education. That is, although Western observers are apt to view global policy trends over the past several decades as novel, in fact they are only experiencing what non-Western countries have encountered since the beginning of modern education: the inevitability of thinking about education in relation to the wider global context.

One consequence of the fateful combination of Western academic dominance and Western amnesia regarding relationality is that the analytical frameworks utilized in understanding education policy tend to lack a global dimension. As we detail below, the one area of research that retained this extra-national dimension was studies of educational transfer, also called "borrowing" and "lending" (SteinerKhamsi and Waldow 2012; Steiner-Khamsi 2004). Yet, even within studies of educational transfer, the analytical frameworks somehow developed with little serious discussion of wider global significance, resulting in a set of easy conceptual tropes: academic/applied, real/imagined, global/local, etc. (for critique, see Silova and Rappleye 2015). While this work remains important, our aim in this chapter is to go beyond the usual ways of viewing education policy and, in particular, the theme of educational transfer within it: we argue that this growing body of work needs to be (re)contextualized within the larger questions of global significance. Inescapably, this requires that we as researchers think seriously about the values that underpin our scholarship and reflect on what sort of global futures our work seeks to contribute to.

\subsection{Limits of Current Approaches}

America in the 1950 s witnessed a coincidence that gave rise to a global contradiction in education policy studies. Parson's structural functionalism was then dominant in the social sciences. Functionalism held that institutions, including education, 
changed in relation to the particular historical, social, economic, and cultural configurations within a given country. At the same time, America strived for global expansion of its models and, in the context of the Cold War, began to actively promote these ideas worldwide in the form of Modernization Theory as an alternative to Marxism (e.g., Rostow 1971; see also Rappleye 2018). There was a deep confidence that America was leading a universal global trajectory toward a prosperous and peaceful future. The deep contradiction was that education was understood analytically in narrow domestic terms, while change was clearly coming from the outside in the form of Western-led development agencies such as USAID, UNESCO, and the World Bank, in addition to the persisting legacies of Western colonialism (we are apt to forget that dozens of Western colonies existed even as late as the mid-1950s). Western bureaucrats and colonial administrators, joined by like-minded academics and local collaborators, set to the task of finding out how to make functionally efficient education policy to "move" countries toward a future imagined in the image of the West.

This policymaking "logic" only intensified in subsequent decades, particularly after the collapse of the socialist bloc wherein Western solutions enjoyed virtually free reign, reaching a point where education policy studies came to be almost entirely focused on locating narrow "solutions" to predetermined images of "progress." The most obvious examples today are found within OECD and World Bank led projects seeking to gather immense amounts of data and apply the most advanced statistical techniques in analysis to isolate "what works" in raising students' achievement (Auld and Morris 2016). Even initiatives such as Education for All (EFA), the Millennium Development Goals (MGDs), and more recently the Sustainable Development Goals (SDGs) reveal a similar focus on minute technical issues without serious discussion of the larger direction and future course (e.g., how to measure progress toward SDG 4, rather than on clarifying what the key term "sustainability" might mean). And while it is easy for critical scholars to disparage these attempts as naïve, in fact the field of education policy studies remains overwhelmingly tied to the functionalist research agenda: it seeks to "fix" education with norms anchored in an unexamined faith in the Western future.

Running counter to these trends within the broader field of education policy studies is research on policy transfer. It has long refused the functionalist fantasy that education can be understood in domestic terms alone. It remains focused on the movement of policies across borders and cognizant of global entanglements. Theoretical frameworks utilized in this area such as World Culture Theory and World Systems Theory actively champion a move beyond functionalism. In this sense, the policy transfer research is leading the way, at least in Western contexts, out of the provincialism bequeathed by functionalism.

Nevertheless, we would argue that educational transfer research still remains too limited, too unaware of the narrowness of its implicit assumptions to affect deep change in the way we understand education policy. Concretely, policy transfer research has too often fallen back on a simple distinction between academic and applied research, attempting to define itself against functionalism. In contrast to applied researchers, academic transfer scholars purport to deal "objectively" with 
how transfer occurs, what stages occur in the process, what actors are involved, and what larger social forces are in play (Phillips 2006). This purported objectivity is seen as superior to the normatively laden work of applied researchers, those who seek to intervene in the "real world."

Among this group of "academic researchers," another set of dichotomous distinctions has subsequently arisen, those focused on "global" developments (e.g., work in International Organizations and apex of policymaking) and "local" understandings (e.g., how policy is translated into practice, reinterpreted along the way, or morphs-as-it-moves). This global/local conceptualization has been one of the most defining categories of analysis over the past two decades, often reinforcing previous dichotomies such as West/East and North/South (Larsen and Beech 2014; Takayama 2015; Silova 2012). Some researchers even make a further distinction between what is "real" and "imagined" in the process, pointing out how adoption of global discourses alone does not represent authentic borrowing (Steiner-Khamsi 2004). Despite critiques that such dichotomies have become a cul-de-sac for our research imagination (Silova and Rappleye 2015; Silova et al. 2017), they persist.

As such, these conceptual tools, although once useful in bringing more nuance and clarity to understanding borrowing and lending processes, have not only become tropes in their repeated use over the past two decades, but they also continue to obscure the larger questions of global significance. In the push to become more "objective" than naïve functionalist accounts, research on policy transfer somewhere along the way lost the larger plot. Why are analyses of policy transfer important? What larger project does this body of work contribute to? What sort of future can we imagine from such studies? Although education transfer research escaped the narrowness of functionalism, it never attempted to subsequently contemplate the wider worldview that bestows its work with significance. That is, it has increased in complexity but has largely failed to address its underlying provincialism.

\subsubsection{A New Framework for Education Policy Borrowing}

Can we continue policy transfer research but jettison its underlying Western provincialism, and what would such a project entail? Utilizing the work of Mignolo (2011), we address these questions by presenting a new framework for understanding the nature of education policy studies, comprising five main research trajectories that are shaping global futures. Mignolo (2011) describes five co-existing but competing projects: (1) re-westernization, (2) global reorientation to the left, (3) de-westernization, (4) decoloniality, and (5) spirituality. Figure 1.1 juxtaposes these options turned possible global futures.

Here we are in agreement with Mignolo (2011) who argues that "in the forthcoming decades, the world order will be decided in the struggles, negotiations, competitions, andcollaborationsbetweenfivedifferentandcoexistingtrajectories-without a winner" (p. 33). Our primary goal in this chapter is not to advocate for one specific position or perspective, but instead to call attention to the plurality of projects 
unfolding in our contemporary world. If policy transfer research can be successfully repositioned on this larger and more diverse world-historical map-what Cowen (1996) usefully calls "kosmos" but now needs to be rendered in the plural-we believe research will become more dynamic and debates far richer. Moreover, we as researchers will be forced to think through and clarify our own values. Below we first briefly describe the five trajectories, then in the next section demonstrate what transfer research based on each of these trajectories might look like.

Rewesternization entails the retrenchment and further expansion of the Western liberal model. Most recognizable in the guise of neoliberal policy, the pillars of this project are "saving capitalism," resuscitated, reloaded, and revamped through science and technology. Mignolo (2011) highlights the leading role of the United States in advancing this primarily economic project, pointing specifically to the knowledge dimension: " 'Knowledge for Development' is the unquestioned orientation of the United States in its current project of rewesternizing the world, which is also transparent in the initiation of the World University Forum, in Davos" (p. 36). Mignolo also draws attention to how subjectivity becomes rewritten within this trajectory away from "communal and pluriversal futures" and toward subjectivities of consumerism and, we would add, individualism.

Reorientation to the Left signifies challenges to rewesternization. One half of this project continues existing trajectories of Western thought from within the Western sphere: secularism and ambitions for universality (e.g., Marxism). It continues the hope of, for example, retaking "the commons" from the increased domination of the capitalist logic or reworking existing institutions to foster greater material equality. The other half of this project pursues similar ends but is situated outside of Western Europe: "the Left from a Marxist background, as was introduced and unfolded in colonial countries and subcontinents" (p. 41). Mignolo (2011) argues that scholars

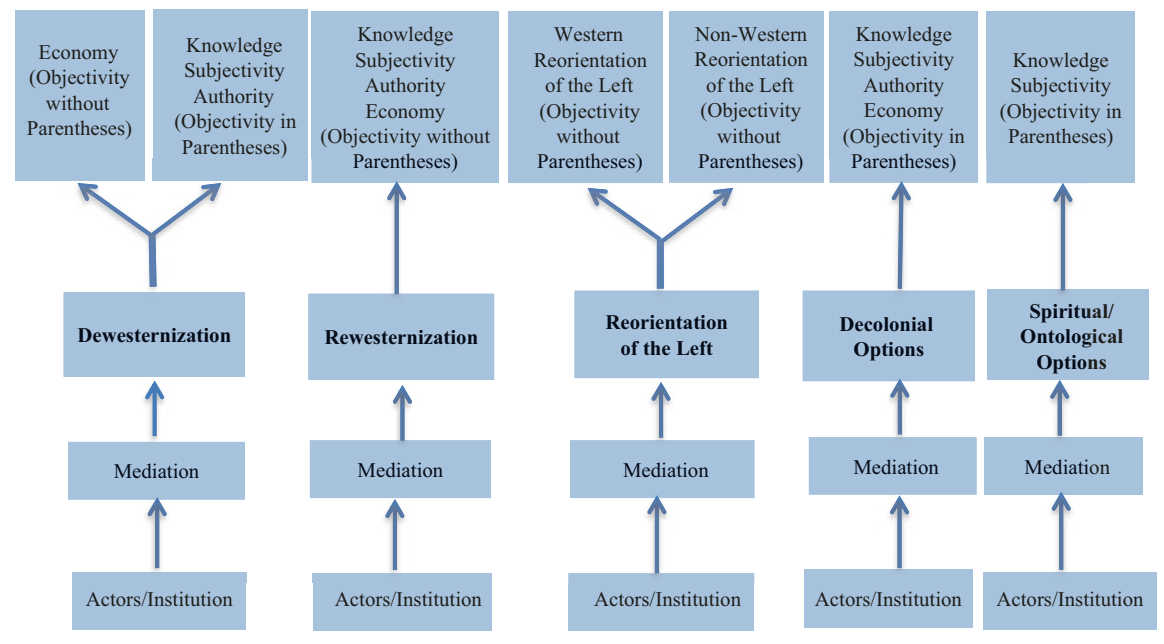

Fig. 1.1 Schematic visualization of five current trajectories of the world order that are shaping global futures. (Source: Adapted from Mignolo 2011: 35) 
working from this perspective face similar challenges as in the West and therefore "must consider to what extent Western political theories and political economy and Western universities (as institutions and curricula) shall be the model for socioeconomic organization and education" (p. 44).

Dewesternization initially appears like a clean break from the Western frameworks of the first two options, but in fact retains and seeks to perfect one half of it: a universally dominant economic trajectory (capitalism). The proposed break comes instead with Western epistemology and the means through which it is projected: "While dewesternization shares with rewesternization the 'survival of capitalism,' the confrontation takes place at other levels of the colonial matrix of power: the sphere of authority, of knowledge, and of subjectivity" (p. 47). Mignolo highlights China as exemplar of this position: China increasingly rejects Washington's dictates as it grows more confident with its global leadership role, yet the politically driven resuscitation of Confucianism is, Mignolo asserts, largely a means of accelerating the move toward China taking control of the locus of global authority. That is, China seeks not to change the structure and hierarchy of a global order created by Western powers and epistemologies, but simply assert control of it.

The Decolonial Option signifies the attempt to divest from forms of Western knowledge imposed during the course of colonialism. The key term here is "delinking," signifying an unhitching from Western economic forms and political authority, but particularly epistemic and subjective starting points. A crucial feature of decoloniality is that "objectivity is in parentheses" which means the end of epistemic universality; the end of the very idea that there exists an "ultimate blueprint for the future" (p. 52). Instead, the decolonial trajectory "means both the analytic task of unveiling the logic of coloniality and the prospective task of contributing to building a world in which many worlds exist" (p. 54). Central to this project is the presence of the Other-an entity that does not share the same basic self-understanding, a challenge that simultaneously defamiliarizes one's own frameworks and suggests alternatives.

Last, the Spiritual Option is an attempt to decolonize at an even deeper level, centered on the triad of knowledge, subjectivity, and religion. Utilizing the word "spirituality"- a term we ourselves feel hesitant about and feel is better read as the Ontological Option, as discussed below-Mignolo recognizes that the modernist assumption of secularism continues to operate within decolonial discussions. As such, it is necessary to "decolonize religion to liberate spirituality" (p. 62). Lest this be understood as a mere dropping out from the larger materialism plot and universe of responsibility, Mignolo recognizes that rethinking the spiritual foundations is crucial for the general direction of delinking from Western modernity: "the common ground for all these re-inscriptions of spirituality is the desire to find ways of life beyond capitalism and its magic of modernity and development that keeps consumers caught in the promises of dreamworlds" (p. 62). More constructively still, what the spiritual option offers is "the contribution of opening up horizons of life that have been kept hostage (that is, colonized) by modernity, capitalism, and the belief in the superiority of Western civilization" (ibid). 
Based on this brief summary of Mignolo's (2011) pluriversal global futures, we now turn to (re)classify empirical studies of educational transfer according to their implicit commitments to one or more of these trajectories. Importantly, we assume that anyone, thinking and writing from anywhere, can participate in any of these projects. That is, the decolonial option is not reserved for scholars in former colonies but can be undertaken from anywhere. Meanwhile, the rewesternization project can be undertaken in both Pondicherry and Paris, and Wuhan and Washington. Mignolo writes: "There is no one-to-one relation between actors and trajectories, although actors make their options at the intersections of their biography, their desires, and the available option" (p. 69). This underscores a key point. As educational policy scholars, we are responsible for reading the wider kosmos and understanding where our work fits. Our work-educational policy transfer research-is itself a form of decision-making about the future, one Mignolo calls mediation: "Disputes for knowledge are fought at the level of mediations. For it is in knowledgemaking and argument-building that decisions take place" (p. 67). We submit that educational researchers can no longer escape this decision-making about the global future by retreating to the easy tropes of research to date, unhitched from a wider global plot.

\subsection{Toward Multiple Global Trajectories: Agenda for Education Policy Research}

In what follows we discuss each trajectory toward global futures separately with a focus on education policy transfer research, while keeping in mind that these trajectories are not fully divergent and may overlap in various ways.

\subsubsection{Rewesternization}

Stemming from the historical foundations of Western civilization and the accompanying spread of Christianity and colonialism, the project of rewesternization attempts to maintain the global hegemony of the West by protecting and extending privileges acquired over the past 500 years (Mignolo 2011). While overt colonization is no longer politically viable, the project of rewesternization nevertheless continues the Western civilizing mission through new political, economic, social, and racial reconfigurations, ranging from modernization and international development efforts to humanitarianism and anti-terrorism campaigns. At its core, rewesternization is about securing the global future for capitalism, market economy, and democracy, as well as the philosophical tenets of liberalism that underpin it. It attempts to rebuild, or prop up, a flagging global confidence in the leadership of the United States and Western Europe. 
Whereas global economic policy discussions have focused on the goal of "saving capitalism," or "reimagining" its future, especially since the global financial crisis of 2008 (Mignolo 2011), rewesternization efforts in education have translated into the global policies that promote the idea of "knowledge for development," or, more specifically, knowledge for economic development and growth. As resources become increasingly limited, both in physical and political terms, it is clear that "the control of scientific and technological knowledge is the card the West shall [continue to] play" in an attempt to maintain its global competitiveness and control (Mignolo 2011: 49). In fact, the World Bank's World Development Report (1998) spelled this out in utmost clarity over two decades ago: "knowledge, not capital, is the key to sustained economic growth and improvements in human well-being." In another iteration, the seminal report Constructing Knowledge Societies (World Bank 2002) maintained that "social and economic progress is achieved primarily through the advancement and application of knowledge" (p. xix) (see Rappleye and Un 2018).

Underpinning the idea of "knowledge for development" is a set of assumptions associated with the concept of "neoliberalism," postulating that markets should play a fundamental role in determining educational purposes, priorities, and policies. Rather than viewing education as a public good, the neoliberal education reform agenda has redefined education to serve private interests, restricting its purposes to the pursuit of increased individual productivity and economic growth (for critique see Ball 2007, 2012; Rizvi and Lingard 2010; Morris 2016). The agenda is being driven by many powerful actors, including corporations (such as Pearson), international financial institutions (such as the World Bank and International Monetary Fund), European Union (EU), the United Nations Education, Scientific and Cultural Organization (UNESCO), the Organization for Economic Cooperation and Development (OECD), as well as a network of private sector coalitions (such as including Hewlett and Gates Foundations).

The substance to this neoliberal rewesternization agenda is provided by comparative policy studies (often commissioned by the World Bank and OECD), which claim that improvements on global learning assessments such as PISA (i.e., an increase in "knowledge" defined as "twenty-first century skills") automatically lead to higher Gross Domestic Product (GDP) growth rates (see Hanushek and Kimko 2000; Hanushek and Woessmann 2007, 2010, 2012, 2015, 2016). The World Bank's work is duly based on the premise that "education builds human capital, which translates into economic growth" (World Bank 2018: 41). Similarly, the OECD has propelled the neoliberal agenda through its many publications - such as Employment and Growth in the Knowledge-Based Economy (Foray and Lundvall 1996) or The Knowledge Economy (1996) — as well as using its Programme for International Student Assessment (PISA) to promote a link between education and economic growth. Both the World Bank's SABER and the OECD's Education at a Glance series are subsequently presented as a guide to the "correct" reading of the datasets, collating information on participating societies to provide a source for identifying "best practices" and initiating transfer.

Meanwhile, education policy entrepreneurs, experts, and consultants have stepped up as intermediaries to "translate" PISA data into "best practices," promot- 
ing - and profiting from - the uptake of neoliberal reforms globally (Auld and Morris 2014; Verger 2012; Silova 2012). This industry will be further extended and legitimated under the OECD's (2018) Learning Framework 2030, which is aligned with the UN's post-2015 goals as part of the organization's vision for a "new paradigm for development." The "new" vision uses universal metrics to set nations on an "improvement journey", on which they will be supported by a global policy network and partnerships with private organizations. It should be noted that this trajectory is not somehow located "outside" the field: the underlying logic is often casually replicated in academic settings, both in consultancy projects oriented toward influencing policy and in research studies developed for an academic readership. The combination of this network of academics, consultants, and international agencies has thus contributed to both scientific legitimation and practical implementation of the rewesternization project itself.

While the World Bank, OECD, and other international agencies continue to pursue the rewesternization project and the neoliberal education agenda associated with it, many education researchers and policymakers worldwide have become increasingly critical. In particular, they have challenged this "new" policy regime for imposing Western-centric lens to understand education across different contexts (Silova 2012), for introducing market principles into public education settings (Verger and Moschetti 2016; Verger 2012; Robertson et al. 2012), for converting education complexity into (Western) "best practices" (Auld and Morris 2016), for insisting on standardization that destroys diverse onto-cultural ecologies (Gorur 2016), for deepening socioeconomic and gender inequities (Stromquist 2016; Unterhalter 2017), or for overlooking other policy alternatives (Edwards and Loucel 2016; Silova 2010).

More importantly, recent studies have cast doubt on the whole validity of the alleged causal relationship between student test scores and economic growth-the bedrock of the rewesternization project today. They argue that the relationship between changes in student test scores and economic growth in subsequent periods is "unclear at best, doubtful at worst" (Komatsu and Rappleye 2017: 170). Broadly speaking, this means that the policy logic underpinning the rewesternization education regime is not only ethically, pedagogically, economically, and politically problematic, but it is also empirically flawed. Such research should be approached with caution by policymakers and researchers who find themselves under pressure to introduce education policy reforms recommended by international financial institutions in the name of economic growth and, by extension, participate in the project of rewesternization.

\subsubsection{Reorientation to the Left}

One of the strongest critiques thus far of the rewesternization project has come from a competing global trajectory-"reorientation of the Left"-which encompasses different leftist orientations seeking visions of alternative non-capitalist futures. 
Following Mignolo (2011), these orientations include the secular Marxist Left, the Global Left that emerged in the World Social Forum (WSF) as a response to the foundation of the World Trade Organization (WTO), as well as "modern/colonial Left" that has unfolded in former colonial settings (South America, Caribbean, the Middle East, etc.). Underpinning the theoretical foundations of these different leftist orientations are dependency theory and world-system analysis that aim to explain "the differential power of nation states located hierarchically within the worldeconomy" in the face of the unequal distribution of wealth, resources, and wellbeing (Griffith and Arnove 2015: 95; see also Clayton 1998 and Wallerstein 1983, 1995). In this context, the "re-orientation of the Left" project seeks to engage in developing "educational policies and practices that can help to create more peaceful, just and democratic futures" (Griffith and Arnove 2015: 90).

In the comparative study of education policy transfer, the "re-orientation of the Left" is visible in the empirical studies directly critiquing the rewesternization project and mapping alternative education trajectories of the Global Left. Such a twoprong approach enables researchers and policy makers to transform a "language of critique" into a "language of possibility" (Giroux 1997: 108). In particular, a sustained critique of the unequal power dynamics inherent in the North-South education transfer has led many researchers to investigate a South-South cooperation and grassroots mobilization as possible ways to build more symmetrical relationships between the lenders and borrowers of education policies and practices (see Chisholm and Steiner-Khamsi 2008; Jules and Morais de sá e Silva 2008; de sá e Silva 2009). In the context of international development, South-South transfer has been conceptualized as "a way out of the dependency trap in educational development," offering new forms of collective mobilization to overcome global inequalities (SteinerKhamsi 2009: 242).

Scholars have approached the study of the South-South transfer from multiple angles, ranging from cooperation initiatives at the nation-state level to transnational social movements to community-driven forms of political mobilization. For example, Hickling-Hudson (2004) calls attention to the governmental efforts to pursue South-South cooperation in the context of the post-Cold War world. In particular, she examines Cuba's international educational assistance to schools in Jamaica and Namibia as an example of "South-South collaboration which would be independent of traditional direction and financing with strings from the wealthy countries of the "North"” (p. 308). In such relationship, the countries of the "South" attempt to reduce their dependence on the "North" by assisting each other in the process of building "radically new relations" necessary to ensure independence from the "North" in education and other fields. For example, some Caribbean governments have assisted Cuba with solidarity and trade, while Cuba — with its comparatively large proportion of scientists and research capacity-has assisted countries of the Latin America region with several hundred tertiary education scholarships and teacher exchanges within a cost-sharing framework. While recognizing that Cuba's education model is "an imperfect modernist one," Hickling-Hudson (2004) nevertheless argues that it has the potential to "energize alternative postcolonial thinking, a necessary step in facilitating the building of a high quality of 'education for all' " (p. 309). 
In addition to intergovernmental efforts that advance visions of alternative noncapitalist futures, many studies have focused on the grassroots initiatives pursuing leftist agendas in response to the neoliberal project. From a progressive leftist perspective, participation in a market economy reproduces the neoliberal social order and exacerbates various systems of oppressions such as patriarchy, racism, and sexism, among others (Edwards and Klees 2012; Stromquist 2016; Apple 2010; Torres 2002). This means that the concept of participation itself needs to be redefined in "a way that goes beyond being an actor in the market" but rather reflects empowerment that entails "more just and democratic relations among peoples" and facilitates "the involvement of average people in the making and implementing of those decision and policies which affect their lives" (Edwards and Klees 2012: 59). Scholars working within this research trajectory have examined various alternative forms of education participation that purposefully challenge the capitalist regime, ranging from the Landless Workers' Movement in Brazil (Tarlau 2012; McCowan 2003) to Escuela Nueva in Colombia (Luschei 2004) and BRAC Non-Formal Primary Education Program in Bangladesh (Nath 2002). While different in nature, orientation, and scope, these grassroots initiatives have aimed to develop and implement education alternatives to a market-based rewesternization project in their local contexts and, when successful, transfer their experiences beyond national borders.

On a global level, civil society organizations, nongovernmental organizations, citizen associations, and teacher unions have mobilized into transnational advocacy networks to target the neoliberal agendas of international financial institutions at scale. For example, Mundy and Murphy (2001) describe how the establishment of Education International, a global association of teachers' trade unions, in 1993 signaled "a renewed solidarity and internationalism among teacher unions" and "a new era of cooperation between international trade union associations and other international nongovernmental actors around a common agenda for global change" (p. 107). While the main concern of teacher unions historically revolved around the international standards of the teacher status, Education International rearticulated its aims in response to the threat to teachers, and to public education more generally, posed by austerity and the new policy agenda in the late 1990s. In 1999, Education International joined forces with Oxfam and Action Aid-forming a new transnational alliance - to lead the Global Campaign for Education in an attempt to democratize global education governance (Edwards and Klees 2012; see also McPhearson 2016; Mundy and Murphy 2001). As Mundy and Murphy (2001) argue, such transnational advocacy networks have the potential "to contribute to the development of civility and democracy at the international level" by reframing of global educational needs and reshaping of decision-making processes in the field of international educational cooperation (p. 126).

Despite the variations within the "reorientation of the Left" trajectory, these projects have one thing in common-they all strive to create visions of non-capitalist futures that offer alternative universalist logics for a "socialism for the 21 st century" (Mignolo 2011: 39). All tend to assume that a global mobilization of the Left is the most promising way to challenge the hegemony of Western capitalism. However, as Mignolo (2010) insightfully notes, it is important that any strategies toward the 
future-socialist, capitalist, or other-avoid "the modern and imperial temptation of the good and best universal" that would replace the existing ones (p. 354). Given that both capitalist and socialist projects stem from the foundations of Western modernity claiming universality, Mignolo (2010) argues that re-imagining the Global Left as a new universal project "means falling back into the old house while just changing the carpet" (Mignolo 2010: 354). In other words, "re-orientation to the Left" does not leave much space for imagining alternative worlds and worldviews beyond Western modernity.

\subsubsection{Dewesternization}

Mignolo (2011) points out that empirical cases of dewesternization can be found with the greatest intensity in East and Southeast Asia. In many of these countries, there has been a confrontation with Western epistemology and "the structure of enunciation," i.e., the domination of forms of knowledge that remain European and White. Nonetheless, here the flavor is not completely anti-western, as dewesternization shares the same underlying commitment to capitalism and modernity: "it is not a movement of anti- but self-affirmation" (p. 47).

Empirical examples of education policy transfer from the region support this vision. Given that the number of empirical cases is far fewer than work in the two dominant trajectories outlined above, we opt to focus only on the two most salient. Shibata (2006) illustrates how Malaysian political elites in the 1980s-1990s initiated a "Look East" campaign that took Japan as its exemplar, importing policies, policy experts, and training schemes. At first glance, this appeared as a break from the Western world. But, in fact, this referencing functioned more as a political tool to accelerate political, economic, and social consolidation: "Look East as well as learning from Japan were political metaphors for Anti-Western and pro-Asian region based policies. The metaphors were useful in enabling the Malaysian people to understand the goals they had to pursue and the outcomes they could gain rather than abstract notions of political ideas or ideology" (p. 655). Herein "Confucianism" functioned as a discursive technology to accelerate capitalism and political projects of the ruling elite and a move at "deracialization" of legitimate knowledge, but not the more challenging move to rethink capitalism or modernity.

Singapore arguably went much further. Avenall (2013) describes how Singapore launched a "Learn from Japan" campaign, detailing the actual import of institutions such as the police box system (koban) and quality control circles. Singapore also attempted to launch worker productivity campaigns and experimented with Japanese style labor-management relations, both aimed at molding Singaporean workers in the image of industrious, harmonious Japanese. In education, there were also initiatives to bolster moral education. Key to all of this was a discourse of "Asian Values," as loudly promoted by Singaporean Prime Minister Lee Kwan Yew. It revolved around the idea that "Asians" preferred social harmony, placed greater emphasis on the collective, and adhered to loyalty toward authority (see Bangkok Declaration 
1993). Yet Avenall (2013) concludes that rather than a decisive break from capitalism and modern statehood, the Learn from Japan campaign and its associated borrowing are better understood in terms of providing "ideological utility in teaching people about being productive, patriotic, and compliant Singaporeans and in legitimating the persistence of authoritarian governance and neoliberal developmentalist economics" (p. 45). That is, Singapore's government-led attempts to transfer policies from Japan sought to fulfill capitalism and Western modernity, but on its own terms; to self-affirm its own knowledge in the process of convergent capitalist expansion and acceleration. China's contemporary combination of unabated capitalist expansion and its recent turn to replace the ideology of state socialism with "Confucian familism" (Vickers and Zeng 2017: 334) appears to replicate this now familiar pattern (see also Sahlins 2015).

While research has elucidated how policy transfer, as both substance and discourse, is utilized in political processes of dewesternization, it is also possible to imagine academic research that operates within a dewesternization framework, regardless of the empirical object. Take for example, an article by leading Chinese comparative education Gu Mingyuan entitled "Learning from Each Other: a comparative study of education in China and Japan" (1995) wherein he argues:

\footnotetext{
All-around moral intellectual and physical development is a common objective of educational systems in China and Japan. In particular, the two countries place a lot of stress on moral development. This is a tradition of Oriental culture, and can trace its origins to Confucianism. Moral education, or the perfection of personal character, is the core of Confucian virtue. (Gu 1995 [2001]: 202)
}

While this initially appears identical with the discussions of Malaysia and Singapore above, in fact, at this time Confucianism was still not a topic encouraged by the Chinese government. To this day, there is no explicit Chinese government campaign to "learn from Japan." Instead, Gu was pushing for a dewesternization reading of practices in Japan. The sole focus on "moral development," however, reveals an implicit commitment to existing economic goals. The point here is twofold and nuanced: dewesternization always exists for scholars as one larger frame within which to situate policy transfer regardless of the larger political discourse, yet what defines it (particularly in contrast to decoloniality) is its acceptance of the underlying economic and political status quo, as well as its insistence upon self-affirmation rather than confrontation (anti-) with Western modernity. This in-built ambivalence is one reason why dewesternization work so often comes under critique: it sometimes has difficulty explaining the deeper driver of its self-affirmative move to replace the outer packaging of existing structures with "vernacular" symbols.

\subsubsection{The Decolonial Option}

The decolonial option represents a distinct break with modernity associated with any forms of capitalism, socialism, or other abstract universalisms. It involves a comprehensive "divesting of colonial power" on which Western empires were 
founded and expanded globally (Mignolo 2011: 52). Because coloniality is constitutive of modernity, the pursuit of the decolonial option requires changing "the terms and not just the content of the conversation" (Mignolo 2007: 459). In the history of the modern/colonial world, the content has in fact been changed many times-"by Christianity (e.g. theology of liberation); by liberalism (e.g., the US support of de-colonization in Africa and Asia during the Cold War) and by Marxism (also supporting de-colonization in Africa and Asia during the Cold War)" (p. 459). Yet, these changes in content have not challenged the hegemony of Western modernity, leaving its colonial foundations and operational logic intact. Therefore, delinking from modernity/coloniality needs to start with the epistemic and ontological shift in order to bring to the foreground alternatives, i.e., other principles of knowledge, understanding, and being. According to Mignolo (2007), such a shift will ultimately lead to pluriversality, opening spaces for multiple ways of understanding the world, society, education, and being.

One example of an epistemological delinking is Kuan-Hsing Chen's Asia as Method (Chen 2010), which offers a decolonial, de-imperial, and de-Cold War analytical framework that moves research beyond Western-centric interpretations of history and enables scholars to imagine historical experiences in Asia as "an alternative horizon, perspective, and method for posing a different set of questions about world history" (p. xv). Building on Mizoguchi Yūzō's (1966/1989) "China as method" and Takuchi Yoshimi's (1960) "Asia as method," Chen (2010) has analytically approached "Asia" as both a geographic region and a constructed culturalpolitical space with complex, contested, and intertwined historical relations within the region and with the "West." By reorienting the conventional reference points away from the "West" and instead focusing on knowledge "inter-referencing" within the Asian region, Chen (2010) re-centers Asia "as the source of a multiplicity of new [knowledge] flows" (p. 8), thus effectively interrupting the hegemony of Western knowledge and offering a new view on global history. Furthermore, he proposes to explore "how local history, in dialectical interaction with the colonial and other historical forces, transforms its internal formation on the one hand and articulates the local to world history and the structure of global capital on the other hand" (p. 66). In other words, "Asia as method" opens ways to bring to the foreground multiple histories, while revealing the relationality and interdependence of different global spaces.

In the field of education, "Asia as method" has inspired research in the areas of science and technology (Anderson 2012), teacher preparation (Ma 2014), curriculum inquiry (Lin 2012; Daza 2013), childhood studies (Burman 2018; Millei, Silova, and Piattoeva 2018; Yelland and Saltmarsh 2013), global citizenship education (Abdi et al. 2015), and comparative and international education (Zhang et al. 2015; Takayama 2016; Silova et al. 2018). These different articulations of "Asia as method" in education reveal that this decolonial project goes beyond a question of geographic focus but also entails a change of analytical approach in education research. In childhood studies, for example, Burman (2018) has followed Chen's framework to develop the concept of "child as method" as a resource for critically interrogating Western models of child development and education and exploring 
alternative theoretical frameworks. In particular, Burman (2018) argues that local, national, and international policies-influenced by Western neoliberal agendashave viewed the child as both "an index, a signifier of 'civilization' and modernity" and "the key arena in which to instill such civilization" (p. 77). Challenging the mainstream narratives that construct the child as "other"-whether an innocent, inferior, or deviant "other" who can develop into a fully human adult through the processes of psychological and pedagogical socialization-Burman (2018) proposes instead to see children as beings (rather than becomings) by shifting attention on the individual and cultural-political subjectivities of children in different contexts. Aiming to disrupt the teleology and linearity implicit in Western child development theories (e.g., such the idea of "growing up"), she joins queer childhood and education theorists who have attempted to understand the diversity of childhood experiences in terms of growing "sideways" (Stockton 2009) or queering the parameters of childhood narratives through a process of "telling it slantwise" (Przybylo and Ivleva 2018). As a result, the "child as method" approach enables researchers to multiply cultural imaginaries of childhood in both research and everyday life, giving way to previously silenced stories and histories to unfold along different nonWestern trajectories.

In addition to research inspired by "Asia as method," important decolonial options have been developed by scholars working with Southern Theory (Connell 2007; Takayama et al. 2017a, b), Epistemologies of the South (Santos 2014; Esteva et al. 2013; Earle and Simonelli 2005), postsocialist/poscolonial studies (Silova et al. 2017), and other decolonial projects. While ranging in theoretical perspectives, methodological approaches, and geographic focus areas, these various projects have two things in common. First, they neither claim universality nor offer an "ultimate blueprint for the future" (Chen 2010: 52). Rather than replacing one epistemology with another or others, these decolonial projects instead contribute to creating a space where many different worlds and worldviews could coexist on a non-hierarchical basis (Tlostanova 2012; Tlostanova et al. 2016). Second, they aim - both individually and collectively - to fundamentally transform knowledge structure, content, and production, as well as "culture and mind, desire and body" (Chen 2010: $x$ ). These decolonial projects powerfully illustrate that decolonization of knowledge production requires scholars to also engage in decolonizing their subjectivity, so that "the understanding of the self may be transformed, and subjectivity rebuilt" (Chen 2010: 212). For the scholars who continue to live with the consequences of colonial and modern legacies in knowledge and subjectivity, this means reclaiming their positions as epistemic subjects who have both the legitimacy and the capacity to interpret the world from their own origins and lived realities (Silova et al. 2017). Here we locate intriguing intimations that this "resistance" can be done without reinscribing taken-for-granted notions of an active, individualized subject, a move Takeuchi describes as passive "oriental resistance" (see Calichman 2004). Ultimately, decolonization of subjectivity encourages researchers to look outwards "to alternative and multiple forms of identification through the practice of 'becoming others' " (Zhang et al. 2015: 26). In this process, new geopolitics of knowledge 
and being emerge, unsettling the very logic of modernity/coloniality and embracing a global viewpoint that reflects pluriversality.

\subsubsection{The Spiritual (Ontological) Option}

The spiritual option is the least elaborated of the five trajectories and for us emerges as problematic in the way Mignolo (2011) briefly describes it. He argues that "basically stated, the spiritual option advocates decolonizing religion to liberate spirituality" (p. 62), aiming at "finding new ways of life beyond capitalism and its magic of modernity." Unfortunately, this cursory definition suggests that spiritualityemphasis on the Spirit-is something "subjective," something pursued by individuals, and that "religion" (never defined) somehow interferes with it. It appears as a way out of capitalism and retreat from colonialism, but Mignolo's description remains disappointingly vague. And yet, he is clearly on to something: by supporting secular analytical lenses "progressive intellectuals indirectly support capitalist's arguments for modernity and development" (pp. 62-63). To avoid all of this, we instead choose to read the spiritual option as a move beyond materialism or, more challengingly, a gesture toward importance of ontological concern. Hence, we attempt to rename it. It is predicated on the idea that the assumption of a material world of ontological discrete objects that can be known "objectively" is a bedrock of Western science and capitalism, but also a derivative of a particular religious worldview (Christianity). In this reading, the spiritual option moves to open up new ontological possibilities, or if some prefer, metaphysical universes, ones that refuse a secular, materialist worldview as a starting and end point of research. It partially overlaps with recent discussions of the "post-secular turn" (Wu and Wenning 2017; see also Habermas 2008), the ontological turn (Jensen 2017; Holbraad and Pederson 2017), and bears close affinities to work seeking to center spirituality in the academy (Shahajan 2005; Shahjahan 2004; Edwards 2016; Edwards 2020).

We offer three preliminary examples from our recent work, demonstrating how we have tried to operationalize this trajectory in policy transfer related research. The first study explored the origins and drivers of the "Mindfulness" movement in the United States (Rappleye forthcoming). It began by exploring the actors and institutions, and agendas that catalyzed the borrowing of Buddhist meditation techniques into American public schools. It showed how two key actors-US Congressman Tim Ryan and Professor John Kabat-Zinn-carefully reframed these non-Western meditation practices into the language of empirically verified science, emphasizing their practical benefit while downplaying religious dimensions and highlighting similarities with dominant Christian practices. By "silencing" its non-Western and "spiritual" origins, these key actors were able to help Mindfulness successfully gain a foothold and th mainstream. Particularly, John Kabat-Zinn in his book Coming to Our Senses: Healing Ourselves and the World Through Mindfulness (2005) links this "import" of spiritual practices into secular modern institutions to a future beyond capitalism and in recognition of climate change. If transfer research turns to 
focus on new initiatives such as Mindfulness and Yoga that have moved from (usually non-Western) religions into the realm of the "spiritual" and are then inserted into the secular (e.g., schools), we can begin to imagine research that reveals new worldviews anchored in non-material concerns.

A second example is our recent work on temporality, self, and nihilism (Rappleye and Komatsu 2016). At the center of the analysis is the feeling the pervasive sense that life has no meaning — nihilism—a feeling we source to the diffusion of linear time over the past 500 years from its origins in Christian theology. The work draws its legitimacy less from a bevy of statistics and breadth of historical sweep, more from the potential connection with readers who feel something similar. Focusing on the case of Japan, we analyze how the concept of Linear Time was "borrowed" to face the threat of Western colonialism and propagated largely through modern schooling. To analyze the case, we draw not from Western theorists but Japanese thinkers, those adept in synthesizing Western thought and East Asian traditions such as Mahayana Buddhism (e.g., The Kyoto School). This automatically provides a theoretical lens that is "spiritual," forcing readers' attention away from material structures and onto questions such as selfhood and the search for meaning in one's own life. While this initially appears as a flight from the responsibility of scholarly work, in fact it aims to release the central category that underpins "subjectivity," the notion of selfhood itself. In this sense, it is far more radical than even Mignolo (2011) appears ready to imagine: it asks when and how the fundamental categories we use for critique (e.g., subjectivity) arose and why we fail to see other historically specific formations (e.g., clock time) and thus miss its "spiritual" impact upon us.

Our third example brings into focus non-Western worlds and worldviews through the study of nature-centered spiritualities in Latvian early literacy textbooks and children's literature published during the pre-Soviet, Soviet, and post-Soviet periods (Silova 2019). The study reveals that nature-centered spiritualities have survived in Latvian culture and everyday life despite the centuries of Christian crusades and decades of socialist atheism-turned nihilism. However, they have remained mostly invisible in the light of reason, logic, and rationality associated with the European (and later socialist) modernity project, especially social science and education policy research. Yet, this apparent invisibility does not mean that alternative worlds and worldviews disappear or lose their importance in people's lives. Rather, it means that we (as researchers) need to refocus our gaze in order to become aware of the previously unknown or invisible dimensions of our existence. Once we dwell in this space and attune ourselves to it, we can see that Nature's deities continue to live in cultural (and educational) practices, mythological consciousness reveals itself in children's literature through folk stories and fairytales, and spirituality continues to unfold in people's daily lives through ordinary, everyday activities. By contemplating taken-for-granted notions of time and space, Silova's study brings these spiritual domains more clearly into focus, disrupting the established boundaries-between space and time, passion and reason, adult and child, animal and human, self and other-and thus opening a space for (re)imagining education and childhood beyond the Western horizon. 
The spiritual (ontological) option is arguably the least developed of all five trajectories. The reasons for this are several: critical scholars are usually of the modern Marxist-mold and view religion as a mere "opiate" of political deception; postmodern scholars are willing to question everything except their own unexamined secularism and theoretical preeminence; and scholarship in the Western world still largely lacks access to ways of thinking that derive from different ontological worldviews. Moreover, epistemological discussions have dominated ontological contemplation, prompting Shahjahan et al. (2017) to poetically lament that:

This movement toward a "possible way forward" in terms of the adoption of different epistemologies tends to remain within the same ontological parameters that we are trying to transcend because it relies on the same investment needs, reproducing again the circular dance of distraction: we try to change knowing without changing our ways of being. (p. 566)

Future research must develop this trajectory carefully to bring into dialogue different onto-epistemic perspectives, without relegating any of them into the realm of myths or subjective beliefs. Here we have suggested three possibilities that revolve around a similar approach: focusing on an object that is more "spiritual" in nature and attempt to utilize theoretical frameworks not originally forged out of the secular, materialist worldview of the West (hence the natural link to decolonial perspectives that take us beyond the Western horizon). But many more possibilities surely await.

\subsection{Challenges to the Next Generation of Research}

The multiplication of options, rather than the elimination of them, is.... the road to global futures. (Mignolo 2011: 39)

Each of these trajectories outlined above presupposes different understandings of truth and objectivity and, therefore, different approaches to research on education policy transfer. In particular, rewesternization and reorientation to the left trajectories, despite their radically different political, social, and economic orientations, are built on the assumption of "truth without parenthesis," that is, an assumption that there is one objective and universal truth predicated on one ontological reality. In the area of education transfer research, this belief in abstract universalisms has commonly translated into the search for "best policies and practices," which are assumed to be globally relevant, applicable, and transferable. While the dewesternization option strives for self-affirmation in the areas of knowledge, subjectivity, and authority beyond Western hegemony, it nevertheless remains bound to the idea of universal truth and therefore limits research on education transfer to the normativity of functionalism. By contrast, decolonial and spiritual (ontological) options operate on the assumption of "truth in parenthesis," acknowledging that there is not one (objective) truth but rather a multitude. As Maturana (1985) explains, "when one puts objectivity in parenthesis, all views, all verses in the multiverse are equally 
valid. Understanding this, you lose the passion for changing the other" (quoted in Mignolo 2011: 27). From this perspective, there is no longer the need to search for and defend the universal truth; the focus is rather on acknowledging multiple, coexisting trajectories toward the future.

While different in their goals and orientations, four of the five trajectories outlined above-dewesternizaton, the reorientation of the left, decoloniality, and the spiritual (ontological) options-share the common goal of decentering Western hegemony in knowledge and subjectivity. They offer different ways toward the global future that is not exclusively dominated by the rewesternization trajectory but rather delinks from it and unfolds toward pluriversality. According to Mignolo (2007), delinking requires an economic, political, philosophical, and ethical reframing of the terms of the conversation that makes "the Bible, Adam Smith and Karl Marx necessary (because Western categories of thoughts have been globalized through the logic of coloniality and the rhetoric of modernity) but highly insufficient" (p. 459, emphasis added). In other words, decentering Western hegemony does not mean its complete erasure or replacement with other ideologies. Rather than replacing one "truth" (or one hegemon) with another, the critical task is to create "an open horizon of pluriversality" where many different worlds and worldviews can coexist on a non-imperial and non-hierarchical basis (Mignolo 2011: 275). This entails both "unlearning" the terms of modern/colonial knowledge production and ways of being and learning to attune to, acknowledge, and engage with multiple interconnected (and always relational) worlds.

Moving toward pluriversality thus presents several challenges to researchers of education policy studies. In the introduction, we flagged two dominant characteristics of current work: a continued commitment, albeit not always explicit, to functionalism and a persistent tendency toward dichotomous thinking (e.g., global/local, real/imagined, objective/subjective). In the deafening silence over values and contemplations of the future, existing policy research must rethink its approach at a fundamental level if it is to contribute to pluriversality. Here we flag two moves that must come to replace our current commitment to functionalism and dichotomy.

The first move requires awareness of both one's own values and the ways that one's research embodies such normative commitments. It demands not "objectivity" in contradistinction to "applied" researchers, but an awareness of how values are already inherent in whatever form of research we participate in. As discussed, choices of research objects are "mediations": inherently normatively laden decisions in favor of one or another possible future. And contemplating these choices helps us understand our-selves: "Questioning the material, epistemic and ontological fabric that 'we' have created - and that in turn has created a part of 'us'-necessarily means to question ourselves. Who are 'we' supposed to be after all, if we 'transform'?" (Schultz 2017: 137). Through a functionalist lens, an objective world comes under the refined eye of a skilled policy analyst. Unfortunately, that same lens not only renders values invisible but also suggests that change need only occur in the world "out there."

Second, and closely connected to this, is the move from dichotomy to relationality. Dichotomies signify two options, both equally ambitious in their claims to 
universality. In the landscape of binaries foregrounded by a horizon of universality, our collective energy is dissipated in either waging war against the "other side" or turning away from each other completely. It is by now no secret that so many of the binaries that structure existing educational work-even self-proclaimed critical work-is still predicated on distinctions hardened to the point of antagonism during the long sweep of modernity: man/woman, nature/culture, subjective/objective. In contrast, a pluriverse acknowledges more than two options, spaces in-between, and more than one ontological reality. At the same time, it recognizes that "mediations" on future trajectories arise only in relation to different mediations. That is, we need to produce work not only about relationships but also from relationships. To write only about relationships is to fall back into the objectivist conceit and ensure a future of antagonism, rather than sympoiesis (Haraway 2016). ${ }^{1}$

\subsection{Conclusion}

In this chapter, we attempted to go beyond the usual ways of viewing educational policy and the theme of educational transfer within it; we sought to replace the implicit, un-thought backdrop of existing studies within a new worldview and ontoepistemic range of possibility - an admittedly ambitious move to replace both the kosmos and episteme (Cowen 1996) of existing research to set up the possibility for pluriversality. Drawing on Mignolo (2011), we renamed research as "mediations": decisions about what sort of future will unfold. We then reviewed existing research, providing examples of the sorts of work that articulate different trajectories.

What is missing from all this is the significance of our title: Why is it necessary to move beyond the Western horizon to bring about the pluriverse, and what would such research entail? Here we envisage three distinct meanings, albeit all interwoven and interconnected at the most fundamental level. First, there can be no doubt that the biggest threat to the pluriverse at present is the acceleration of the rewesternization trajectory. With the rollout of each new OECD metric-from "Baby PISA" (International Early Learning and Child Well-being Study) to PISA for Development (extending to the developing world) to PISA4U (The Online Programme for School Improvement)—and the transfer of every new "best practice" associated with these new metrics, multiple meanings are rendered increasingly less visible. It is not that these meanings are actually erased, but instead they become harder to see, buried under a layer of Western symbols. Concretely, we may "see" Japanese education on, say, PISA league tables, but these familiar symbols

\footnotetext{
${ }^{1}$ Restricted by space we cannot extend the discussion fully to its post-anthropocentric implications and the obvious connections it has to the environment. Yet we agree with recent concerns voiced by scholars like Haraway among others that the limits of relationality necessarily extend beyond the intra-human horizon. For some indication of future directions we seek to develop in coming years vis-à-vis relationality and the environment, see Silova et al. (2020), Komatsu et al. (2019), and Rappleye and Komatsu (2016).
} 
betray a complex reality below, tempting us to mistake the symbol for the signified. Yet, the only way to become clear of the differences is to move beyond the horizon of Western symbols, to refuse the familiarity offered up by the rewesternization narrative. It is inconceivable that a pluriverse could arise from a ground already mediated by rewesternization priorities.

The second meaning entails a realization that the Western horizon is not simply an on-going political project (i.e., rewesternization) but a set of perspectives embedded in our epistemic and methodological choices. As outlined in the introduction, the analytical toolkit of most education policy scholars has been forged out of the hard certainty of Parsonian functionalism and gains legitimacy by comparing itself favorably against uncritical, "applied" research perspectives. But the toolkit is anything but certain: it was developed inside the Western historical, sociological, and cultural experience, thus limiting our ability to see and understand multiple worlds and worldviews outside of it. As but one example, we may return to the issue raised in introduction: the methodological nationalism of educational policy studies is a non-relational fabrication generated by the functionalist analytical lens. It is virtually impossible to understand this until one finds analytical toolkits built in relation to different non-Western cultural experiences. And this is true even for tools given by, say, post-modernism (e.g., governmentality, policyscapes). We should not forget, as just one poignant example, that Nietzsche's project, which has generated so much new thinking when it passed through the hands of social science luminaries such as Max Weber and Foucault (Owen 1994), drew significant momentum from non-Western thought (see Figl 1991; Scheiffele 1991; Rappleye 2020).

Finally, the Western horizon constitutes many education policy researchers at an even more fundamental layer: the notion of self. Prior to even the choice of analytical tools and research objects stands an implicit set of assumptions about what it means to be or-in this case, to be a scholar. Most scholars taking advanced studies in Western institutions come out subscribing to the Western Enlightenment view of self: Kant's transzendantales Ich. Deemed necessary to make democracy viable, "Kant's answer to the question about what kind of subjectivity needed in a democracy," writes Biesta (2006), "focused on the ability of individuals to make use of their own reason without direction from another" (p. 127). The enlightenment self was to be both rational and autonomous (from the Greek auto, meaning self). These qualities stand in opposition to the relationality and sympoiesis we have been gesturing to throughout this entire piece.

This underscores just how much the Western horizon is both within us and constitutes us: what is presented here as a new idea is really what becomes visible when the Western horizon of subjectivity is loosened up. Ultimately, the move to a pluriverse can be started at the political and analytical layers, but for it to gain momentum, it will need to be anchored in "subjectivity." Given that intellectuals in the West are still so thoroughly imbued with Kantian subjectivity, one of the only ways to get there is to move beyond the Western horizon. Only here, in spaces beyond Western demarcations, does pluriversality become possible, opening endless opportunities for conversations and mutual learning across different epistemic and ontological realms. 


\section{References}

Abdi, A. A., Shultz, L., \& Pillay, T. (2015). Decolonializing global citizenship education. Rotterdam: Sense Publishers.

Anderson, W. (2012). 'Asia as method' in science and technology studies. East Asian Science, Technology and Society, 6(4), 445-451.

Apple, M. (2010). Globalization, social justice, and education. New York: Routledge.

Auld, E., \& Morris, P. (2014). Comparative education, the 'New Paradigm' and policy borrowing: Constructing knowledge for education reform. Comparative Education, 50(2), 129-155.

Auld, E., \& Morris, P. (2016). PISA, policy and persuasion: Translating complex conditions into education 'best practice'. Comparative Education, 52(2), 202-229.

Avenall, S. (2013). Beyond mimesis: Japan and the uses of political ideology in Singapore. In P. Morris, N. Shimazu, \& E. Vickers (Eds.), Imagining Japan in Post-War East Asia: Identity politics, schooling, and popular culture (pp. 29-48). London: Routledge.

Ball, S. (2007). Education PLC: Understanding private sector participation in public sector education. London: Routledge.

Ball, S. (2012). Global education Inc.: New policy networks and the neoliberal imaginary. New York: Routledge.

Biesta, G. (2006). Beyond learning: Democratic education for a human future. New York: Routledge.

Burman, E. (2018). Child as method: Implications for decolonising educational research. International Studies in the Sociology of Education, . Forthcoming.

Calichman, R. (2004). Takeuchi Yoshimi: Displacing the west. Ithaca: Cornell East Asia Series.

Chen, K. H. (2010). Asia as method: Toward deimperialization. Durham: Duke University Press.

Chisholm, L., \& Steiner-Khamsi, G. (2008). South-south cooperation in education \& development. New York: Teachers College Press.

Clayton, T. (1998). Beyond mystification: Reconnecting world-systems theory for comparative education. Comparative Education Review, 42(4), 479-496.

Connell, R. (2007). Southern theory: The global dynamics of knowledge in social sciences. Crows Nest: Allen \& Unwin.

Cowen, R. (1996). Last past the post: Comparative education, modernity, and perhaps late modernity. Comparative Education, 32(2), 151-170.

Daza, S. L. (2013). Reading texts, subtexts, and contexts: Effects of (post)colonial legacies in/on curricular texts in different contexts. Qualitative Research in Education, 2(3), 206-212.

Earle \& Simonelli. (2005). Uprising of hope: Sharing Zapatista journey to alternative development. Lanham: Altamira Press.

Edwards, S. (2016). Seeking collective wisdom: A spiritual-dialogic approach. In J. Lin, R. L. Oxford, \& T. Culham (Eds.), Towards a spiritual research paradigm: Exploring new ways of knowing, researching, and being (pp. 257-273). Charlotte: Information Age Publishing.

Edwards, S. (2020). Allowing ourselves to reimagine ecologically responsible futures for education research and practice globally: Critiquing the limitations imposed by christian hegemony. East China Normal Review of Education, 3(1), 164-168.

Edwards, D. B., \& Klees, S. (2012). Participation in development and education governance. In A. Verger, M. Novelli, \& U. Kosar-Altinyelken (Eds.), Global education policy and international development: New agendas, issues and programmes (pp. 55-76). New York: Continuum.

Edwards, D. B., \& Loucel, C. (2016). The EDUCO program, impact evaluations, and the political economy of global education reform. Education Policy Analysis Archives, 24(92), 1-45.

Esteva, G., Babones, S., \& Babcicky, P. (2013). The future of development: A radical manifesto. Chicago: Policy Press.

Figl, J. (1991). Nietzsche's early encounters with Asian thought. In G. Parkes (Ed.), Nietzsche and Asian thought (pp. 51-63). Chicago: University of Chicago Press. 
Foray, D., \& Lundvall, B. (1996). The knowledge-based economy: From the economics of knowledge to the learning economy. Employment and growth in the knowledge-based economy. Paris: OECD.

Giroux, H. (1997). Rewriting the discourse of racial identity: Towards a pedagogy and politics of whiteness. Harvard Educational Review, 67(2), 285-321.

Gorur, R. (2016). Seeing like PISA - A cautionary tale about the performativity of international assessments. European Educational Research Journal, 15(5), 598-616.

Griffith, T., \& Arnove, B. (2015). World culture in the capitalist world-system in transition. Globalisation, Societies, and Education, 13(1), 88-108.

Gu, M. (2001). Education in China and abroad: Perspectives from a lifetime in comparative education. Hong Kong: University of Hong Kong, Comparative Education Research Centre.

Habermas, J. (2008). Secularism's crisis of faith: Notes on post-secular society. New Perspectives Quarterly, 25, 17-29.

Hanushek, E. A., \& Kimko, D. D. (2000). Schooling, labor-force quality, and the growth of nations. American Economic Review, 90(5), 1184-1208.

Hanushek, E. A., \& Woessmann, L. (2007). Education quality and economic growth. Washington, DC: The World Bank.

Hanushek, E. A., \& Woessmann, L. (2010). The high cost of low educational performance: The long-run economic impact of improving PISA outcomes. Paris: OECD.

Hanushek, E. A., \& Woessmann, L. (2012). Schooling, educational achievement, and the Latin American growth puzzle. Journal of Development Economics, 99(2), 497-512.

Hanushek, E. A., \& Woessmann, L. (2015). The knowledge capital of nations: Education and the economics of growth. Cambridge: MIT Press.

Hanushek, E. A., \& Woessmann, L. (2016). Knowledge capital, growth, and the east Asian miracle. Science, 351(6172), 344-345.

Haraway, D. (2016). Staying with the trouble: Making kin in the Chthulucene. Durham: Duke University Press.

Hickling-Hudson, A. (2004). South-south collaboration: Cuban teachers in Jamaica and Namibia. Comparative Education, 40(2), 289-311.

Holbraad, M., \& Pedersen, M. A. (2017). The ontological turn: An anthropological exposition. Cambridge: Cambridge University Press.

Jensen, C. B. (2017). New ontologies? Reflections on some recent 'turns' in STS, anthropology and philosophy. Social Anthropology, 25(4), 525-545.

Jules, T. D., \& Morais de sá e Silva, M. (2008). How different disciplines have approached southsouth cooperation and transfer. Society for International Education Journal, 5(1), 45-64.

Komatsu, H., \& Rappleye, J. (2017). A new global policy regime founded on invalid statistics? Hanushek, Woessman, PISA, and economic growth. Comparative Education, 53(2), 166-191.

Komatsu, H., Rappleye, J., \& Silova, I. (2019). Culture and the independent self: Obstacles to environmental sustainability. Anthropocene, 26. doi.org/10.1016/j.ancene.2019.100198.

Larsen, M., \& Beech, J. (2014). Spatial theorizing in comparative education. Comparative Education Review, 58(2), 191-214.

Lin, A. M. (2012). Towards transformation of knowledge and subjectivity in curriculum inquiry: Insights from Chen Kuan-Hsing's 'Asia as method'. Curriculum Inquiry, 42(1), 153-178.

Luschei, T. F. (2004). Timing is everything: The intersection of borrowing and lending in Brazil's adoption of Escuela Nueva. In G. Steiner-Khamsi (Ed.), The global politics of educational borrowing and lending. New York: Teachers College Press.

Ma, W. (Ed.). (2014). East meets west in teacher preparation: Crossing Chinese and American borders. New York: Teachers College Press.

Maturana, H. (1985). Interview. Minding Ecology [Online]. Available: http://www.oikos.org/ maten.htm.

McCowan, T. (2003). Participation and education in the landless people's movement of Brazil. Journal for Critical Education Policy Studies, 1(1), 1-18. 
McPhearson, I. (2016). An analysis of power in transnational advocacy networks in education. In K. Mundy, A. Green, B. Lingard, \& T. Verger (Eds.), The handbook of global education policy (pp. 401-418). New York: Wiley-Blackwell.

Mignolo, W. (2007). Delinking. Cultural Studies, 21(2), 449-514.

Mignolo, W. (2010). The darker side of western modernity: Global futures, decolonial options. Durham, NC: Duke University Press.

Mignolo, W. D. (2011). The darker side of Western modernity: Global futures, decolonial options. Durham: Duke University Press.

Millei, Z., Silova, I., \& Piattoeva, N. (2018). Towards decolonizing childhood and knowledge production. In I. Silova, N. Piattoeva, \& Z. Millei (Eds.), Childhood and schooling in (post) socialist societies: Memories of everyday life (pp. 231-256). New York: Palgrave Macmillan.

Morris, P. (2016). Education policy, cross-national tests of pupil achievement, and the pursuit of world- class schooling: A critical analysis. London: IOE Press.

Mundy, K., \& Murphy, L. (2001). Transnational advocacy, global civil society? Emerging evidence from the field of education. Comparative Education Review, 45(1), 85-126.

Nath, S. (2002). The transition from non-formal to formal education: The case of Brac, Bangladesh. International Review of Education, 48(6), 517-524.

OECD. (2018). The future of education and skills: Education 2030. Paris: OECD.

Owen, D. (1994). Maturity \& modernity: Nietzsche, weber, Foucault, and the ambivalence of reason. London: Routledge.

Phillips, D. (2006). Investigating policy attraction in education. Oxford Review of Education, $32(5), 551-559$.

Przybylo, E., \& Ivleva, P. (2018). Teaching it straight: Sexuality education across post-statesocialist contexts. In I. Silova, N. Piattoeva, \& Z. Millei (Eds.), Childhood and schooling in (post) socialist societies: Memories of everyday life (pp. 183-203). New York: Palgrave Macmillan.

Rappleye, J. (forthcoming). Borrowing Buddhism? Mindfulness in American classrooms, ontology in comparative education [Under Review].

Rappleye, J. (2018). Borrowings, modernity, and de-axialization: Rethinking the educational research agenda for a global age. In A. Yonezawa, Y. Kitamura, B. Yamamoto, \& T. Tokunaga (Eds.), Japanese education in a global age: Sociological reflections and future directions (pp. 53-74). Singapore: Springer-Nature.

Rappleye, J. (2020). Comparative education as cultural critique. Comparative Education, 56(1), 39-56.

Rappleye, J., \& Komatsu, H. (2016). Living on borrowed time: Rethinking temporality, self, nihilism, and schooling. Comparative Education, 52(2), 177-201.

Rappleye, J., \& Un, L. (2018). What drives failed policy at the World Bank? An inside account of new aid modalities to higher education: Context, blame, and infallibility. Comparative Education, 54(2), 250-274.

Rizvi, F., \& Lingard, B. (2010). Globalizing education policy. London: Routledge.

Robertson, S. L., Mundy, K. E., Verger, A., \& Menashy, F. (2012). Public private partnerships in education: New actors and modes of governance in a globalizing world. Cheltenham: Edward Elgar.

Rostow, W. W. (1971). The stages of economic growth. Cambridge: Cambridge University Press.

de sá e Silva, M. (2009). South-south transfer cooperation: Past and present conceptualization and practice. In L. Chisolm \& G. Steiner-Khamsi (Eds.), South-south cooperation in education and development (pp. 39-62). New York: Teachers College Press.

Sahlins, M. (2015). Confucius institutes: Academic malware. Chicago: Prickly Paradigm Press.

Santos, B. (2014). Epistemologies of the south. Justice against epistemicide. Boulder: Paradigm Publishers.

Scheiffele, E. (1991). Questioning one's "own” from the perspective of the foreign. In G. Parkes (Ed.), Nietzsche and Asian thought (pp. 31-47). Chicago: University of Chicago Press. 
Schultz, K. A. (2017). Decolonizing political ecology: Ontology, technology and 'critical' enchantment. Journal of Political Ecology, 24(1), 125-143.

Shahajan, R. (2005). Spirituality in the academy: Reclaiming from the margins and evoking a transformative way of knowing the world. International Journal of Qualitative Studies in Education, 18(6), 685-711.

Shahjahan, R. (2004). Centering spirituality in the academy: Towards a transformative way of teaching and learning. Journal of Transformative Education, 2(4), 294-312.

Shahjahan, R., Ramirez, G. B., \& Andreotti, V. D. O. (2017). Attempting to imagine the unimaginable: A decolonial reading of the global university rankings. Comparative Education Review, 61(S1), S51-S73.

Shibata, M. (2006). Assumptions and implications of cross-national attraction in education: The case of 'learning from Japan'. Oxford Review of Education, 32(5), 649-663.

Silova, I. (Ed.). (2010). Post-socialism is not dead: (Re)reading the global in comparative education. Bingley: Emerald Publishing.

Silova, I. (2012). Contested meanings of educational borrowing. In G. Steiner-Khamsi \& F. Waldow (Eds.), World yearbook of education 2012: Policy borrowing and lending in education (pp. 229-245). New York: Routledge.

Silova, I. (2019). Toward a wonderland of comparative education. Comparative Education, 55(4), 444-472.

Silova, I., \& Rappleye, J. (2015). Beyond the world culture debate in comparative education: Critiques, alternatives, and a noisy conversation. Globalisation, Societies, and Education, 13(1), 1-7.

Silova, I., Millei, Z., \& Piattoeva, N. (2017). Interrupting the coloniality of knowledge production in comparative education: Postsocialist and postcolonial dialogues after the cold war. Comparative Education Review, 61(S1), S74-S102.

Silova, I., Piattoeva, N., \& Millei, Z. (2018). Childhood and schooling in (post)soviet societies: Memories of everyday life. London: Palgrave Macmillan.

Silova, I., Rappleye, J., \& You, Y. (Eds.). (2020). Beyond the western horizon in educational research: Towards a deeper dialogue about our interdependent futures [special issue]. ECNU Review of Education, 3(2), 1-179.

Steiner-Khamsi, G. (2004). The global politics of educational borrowing and lending. New York: Teachers College Press.

Steiner-Khamsi, G. (2009). A way out from the dependency trap in educational development? In L. Chisolm \& G. Steiner-Khamsi (Eds.), South-south cooperation in education and development (pp. 241-258). New York: Teachers College Press.

Steiner-Khamsi, G., \& Waldow, F. (2012). The world yearbook of education 2012: Policy borrowing and lending in education. New York: Routledge.

Stockton, K. B. (2009). The queer child, or growing sideways in the twentieth century. Durham: Duke University Press.

Stromquist, N. (2016). Using regression analysis to predict countries' economic growth: Illusion and fact in education policy. Real-World Economics Review, 76, 65-74.

Takayama, K. (2015). Provincialising the world culture theory debate: Critical insights from a margin. Globalisation, Societies, and Education, 13(1), 34-57.

Takayama, K. (2016). Deploying the post-colonial predicaments of researching on/with 'Asia' in education: A standpoint from a rich peripheral country. Discourse: Studies in the Cultural Politics of Education, 37(1), 70-88.

Takayama, K., Sriprakash, A., \& Connell, R. (2017a). Rethinking knowledge production and circulation in comparative and international education: Southern theory, postcolonial perspectives, and alternative epistemologies. Comparative Education Review, 59(1), 5-8.

Takayama, K., Sriprakash, A., \& Connell, R. (2017b). Toward a postcolonial comparative and international education. Comparative Education Review, 61(S1), S1-S24.

Tarlau, R. (2012). Coproducing rural public schools in Brazil: Contestation, clientelism, and the landless workers' movement. Politics and Society, 41(3), 395-424. 
Tlostanova, M. (2012). Postsocialist $\neq$ postcolonial? On post-soviet imaginary and global coloniality. Journal of Postcolonial Writing, 48(2), 130-142.

Tlostanova, M., Thapar-Bjorkert, S., \& Koobak, R. (2016). Border thinking and disidentification: Postcolonial and postsocialist feminist dialogues. Feminist Theory, 17(2), 211-228.

Torres, C. A. (2002). Globalization, education, and citizenship: Solidarity versus markets? American Educational Research Journal, 39(2), 363-378.

Unterhalter, E. (2017). A review of public private partnerships around girls' education in developing countries: Flicking gender equality on and off. Journal of International and Comparative Social Policy, 33(2), 181-199.

Verger, A. (2012). Framing and selling global education policy: The promotion of public-private partnerships for education in low-income contexts. Journal of Education Policy, 27(1), 109-130.

Verger, A., \& Moschetti, M. (2016). Public-private partnerships as an education policy approach: Multiple meanings, risks and challenges [education research and foresight series, no. 19]. Paris: UNESCO.

Vickers, E., \& Zeng, X. (2017). Education and society in post-Mao China. New York: Routledge. Wallerstein, I. (1983). Historical capitalism. London: Verso.

Wallerstein, I. (1995). After liberalism. New York: The New Press.

World Bank. (1998). World development report 1998/1999: Knowledge for development. New York: Oxford University Press.

World Bank. (2002). Constructing knowledge societies: New challenges for tertiary education. Washington: World Bank. Retrieved January 25, 2015, from http://siteresources.worldbank. org/INTAFRREGTOPTEIA/Resources/Constructing_Knowledge_Societies.pdf.

World Bank. (2018). World development report: Learning to realize education's promise. Washington, DC: World Bank.

Wu, J., \& Wenning, M. (2017). The postsecular turn in education: Lessons from the mindfulness movement and the revival of Confucian academies. Studies in the Philosophy of Education, 35, 551-571.

Yelland, N., \& Saltmarsh, S. (2013). Ethnography, multiplicity and the global childhoods project: Reflections on establishing an interdisciplinary, transnational, multi - sited research collaboration. Global Studies of Childhood, 3(1), 2-11.

Zhang, H., Chan, P. W. K., \& Kenway, J. (Eds.). (2015). Asia as method in education studies: A defiant research imagination. Abingdon: Routledge.

Iveta Silova is Professor and Director of the Center for the Advanced Studies in Global Education at Mary Lou Fulton Teachers College at ASU. She holds a $\mathrm{PhD}$ in comparative education and political sociology from the Graduate School of Arts \& Sciences, Columbia University, USA. Her research has focused on the study of globalization, postsocialist transformations, and knowledge production and transfer in education. More recently, Iveta has been exploring the intersections of postsocialist, postcolonial, and decolonial perspectives in comparative education to envision education beyond Western modernity.

Jeremy Rappleye is Associate Professor at Kyoto University, Graduate School of Education. He holds a doctorate degree from University of Oxford. He has previously taught and studied in mainland China (Yale-China Teaching Fellow, Zhongshan University) and Taiwan (National Taiwan University). His early work focused on the politics and processes of educational transfer in East Asia, situated within wider debates over neo-institutionalism (world culture theory). His more recent research aims to overcome divisions between philosophy and empirical social science on the one hand, and Western (predominantly Anglo-American) perspectives and non-Western perspectives on the other. 
Euan Auld is Assistant Professor at The Education University of Hong Kong. He holds a PhD in International and Comparative Education from the University College London (UCL) Institute of Education. His research to date has focused primarily on international large-scale assessments and their influence on education research and governance, drawing on philosophical perspectives and narrative theory.

Open Access This chapter is licensed under the terms of the Creative Commons Attribution 4.0 International License (http://creativecommons.org/licenses/by/4.0/), which permits use, sharing, adaptation, distribution and reproduction in any medium or format, as long as you give appropriate credit to the original author(s) and the source, provide a link to the Creative Commons licence and indicate if changes were made.

The images or other third party material in this chapter are included in the chapter's Creative Commons licence, unless indicated otherwise in a credit line to the material. If material is not included in the chapter's Creative Commons licence and your intended use is not permitted by statutory regulation or exceeds the permitted use, you will need to obtain permission directly from the copyright holder. 